\title{
PENGARUH KELAS IBU HAMIL TERHADAP KECEMASAN IBU DALAM MENGAHADAPI PERSALINAN DI WILAYAH KERJA PUSKESMAS JATINUNGGAL TAHUN 2020
}

\author{
Ely Walimah ${ }^{1}$ \\ Prodi Sarjana Ilmu Kesehatan Masyarakat STIKes Sebelas April Sumedang
}

\begin{abstract}
ABSTRAK
Kecemasan merupakan salah satu gangguan emosional yang sering dialami ibu hamil, terutama pada primigravida. Salah satu program pemerintah dalam upaya peningkatan kesehatan pada ibu hamil adalah dengan mengadakan kelas ibu hamil. Tujuan diadaknnya penelitian ini untuk mengetahui pengaruh kelas ibu hamiil terhadap kecemasan ibu dalam menghadapi persalinan di wilayah kerja puskesmas Jatinunggal Tahun 2020. Jenis penelitian yang digunakan jenis penelitian yang digunakan yaitu deskriptif analitik dengan desain Cross Sectional

Sampel yang diambil dalam penelitian ini sebanyak 55 responden denganmenggunakan teknik clauster sampling. Variabel independen pada penelitian ini adalah kelas ibu hamil, pendidikan dan umur saerta variable dependen adalah kecemasan. Pengumpulan data menggunakan instrument lembar kuesioner. Data analiss dengan menggunakan Chi Square Tes dengan tingkat signifikansi $\alpha=0,1$. Hasil penelitian menunjukan bahwa kelas ibu hamil $(\mathrm{p}=0,017)$, Pendidikan $(0,030)$ dan umur $(\mathrm{p}=0,034)$ berhubungan terhadap kecemasan ibu dalam menghadapi persalinan.
\end{abstract}

Kata kunci : Ibu hamil, Kecemasan

\section{PENDAHULUAN}

Salah satu upaya pemerintah di bidang kesehatan yaitu terciptanya pelayanan kesehatan yang mudah dijangkau oleh seluruh lapisan masyarakat sebagai langkah aktif pemerintah untuk meningkatkan derajat kesehatan masyarakat serta meningkatkan kualitas hidup manusia. Peningkatan derajat kesehatan serta kualitas hidup manusia harus di mulai sedini mungkin, yaitu sejak manusia dalam kandungan. Priritas utama program kesehatan Indonesia saat ini yaitu peningkatan derajat kesehatan, terutama pada kelompok yang rentan akan kesehatannya, seperti ibu hamil, ibu bersalin, ibu nifas serta bayi pada masa perinatal (Kemenkes,2014).
Di Indonesia angka kematian ibu (AKI) berdasar survey Demografi dan Kesehatan Indonesia Tahun 2017, angka kematian ibu di Indonesia masih tinggi yaitu 359 per 100.000 kelahiran hidup, data ini merupakan acuan untuk mencapai AKI sesuai Sustainable Development Goals yaitu 70 per 100.000 kelahiran hidup pada tahun 2030 (Kemenkes, 2017).

Pada tahun AKI mencapai 748 jiwa, jumlah kematian ibu pada tahun 2015823 jiwa, pada tahun 2016 di Jawa Barat rasio kematian ibu dibawah capaian target, yaitu target yang harus dicapai sebesar 89 per 100.000 kelahiran hidup, dengan realisasi sebesar 86.97 per 100.000 kelahiran hidup (Dinas Kesehatan Provinsi Jawa Barat, 2016). 
Kehamilan bagi seorang wanita merupakan suatu kebahagiaan serta anugrah yang sangat luar biasa. Kehamilan memang nerupakan sesuatu yang membahagiakan, tetapi disisi lain kehamilan juga merupakan suatu hal yang menggelisahkan. Kecemasan pada ibu hamil dipengaruhi oleh perubahan fisik yang terjadi selama kehamilannnya yaitu dengan perut semakin membesar dan badanyang bertambah gemuk (Utami,2011). Kecemasan pada ibu hamil jika tidak ditangani makan berpengaruh buruk terhadap kesehatan ibu serta bayinya.

\section{Rumusan Masalah}

Bagaimana Pengaruh Pelaksanaan kelas Ibu Hamil terhadap kecemasan ibu dalam menghadapi persalinan di wilayah kerja Puskesmas Jatinunggal Tahun 2020.

\section{Tujuan Penelitian}

Menganalis pengaruh kelas ibu hamil terhadap kecemasan yang dialami selama kehamilan di Wilayah kerja Puskesmas Jatinunggal tahun 2020.

\section{METODE PENELITIAN}

Desain penelitian ini adalah penelitian deskriptif analitik, dengan pendekatan cross sectional. Tempat penelitian dilakukan di Puskesmas Jatinunggal Kecamatan Jatinunggal Kabupaten Sumedang. Waktu penelitian dilaksanakan pada Bulan Juni-Juli 2020. Ukuran responden dalam penelitian ini adalah sampel dari ibu hamil dengan usia kehamilan yang menginjak Trimester III di Wilayah kerja Puskesmas Jatinunggal sebanyak 64 orang.
Pengukuran variable kelas ibu hamil, umur dan tingkat pendidikan dengan kecemasan ibu hamil menggunakan lembar kuesioner. Pengukuran kelas ibu hamil dengan menggunakan kuesioner melalui pertanyan keikutsertan responden pada kegiatan kelas ibu hamil. Pengukuran ukur dan tingkat pendidikan dengan menggunakan kuesioner memalui pertanyaan dlm kuesioner.

Variabel kecemasan menggunakan pertanyaan dalam kuesioner.

\section{HASIL DAN PEMBAHASAN}

Ibu hamil yang mengikuti kelas ibu hamil di wilayah kerja puskesmas Jatinunggal labih banyak yaitu 39 ibu hamil sebesar 70.9\%. Rentang usia 20-30 tahun sebanyak 27 orang (49.1\%) dengan tingkat pendidikan terbanyak yaitu lulus SMP sebanyak 23 orang (41.8\%). Adanya hubungan antara pelaksanaaan kelas ibu hamil dengan kecemasan dalam menghadapi persalinan.

Untuk mengatasi kecemasan pada ibu dalam menghadapi persalinan, direncanakan metode pembelajaran kelas ibu hamil ( $p$ value $=0.017)$. Kegiatan ini merupakan sarana belajar bersama tentang kesehatan bagi ibu hamil dalam bentuk tatap muka dalam berkelompok yang bertujuan meningkatkan pengetahuan dan keterampilan ibu-ibu mengenai kehamilan. Kecemasan timbul karena ketakutan kehilangan bayi yang dilahirkan, seperti ketakutan bahwa bayi yang dilahirkan akan meninggal atau cacat. Kecemasan juga dapat muncul akibat perasaan ketidakmampuanmemenuhi kebutuhan bayi 
yang akan dilahirkan, serta munculnya dugaanbahwa melahirkan akan menghambat aktivitas sehari-hari.

\section{SIMPULAN}

Ibu hamil yang mengikuti kelas ibu hamil di wilayah kerja puskesmas Jatinunggal labih banyak yaitu 39 ibu hamil sebesar $70.9 \%$. Rentang usia 20-30 tahun sebanyak 27 orang (49.1\%) dengan tingkat pendidikan terbanyak yaitu lulus SMP sebanyak 23 orang (41.8\%). Adanya hubungan antara pelaksanaaan kelas ibu hamil dengan kecemasan dalam menghadapi persalinan.

\section{DAFTAR PUSTAKA}

Kementrian Kesehatan Republik Indonesia 2014. Pedoman pelaksanaan Kelas Ibu Hamil. Jakarta: Kementrian Kesehatan RI.

Kementrian Kesehatan Republik Indonesia 2017. Pedoman pelaksanaan kelas ibu hamil. Jakarta: Kementrian Kesehatan RI.

Utami, Adan Lestari, W. 2011. Perbedaan Tingkat Kecemasan Primigravida dengan Multigravida Dalam Menghadapi Kecemasan. Jurnal Ners Indonesia. 